\title{
DIAGNOSA PENYAKIT KULIT WAJAH MENGGUNAKAN METODE DECISION TREE DAN ALGORITMA C4.5
}

\author{
Abdul Aziz 1), Karpen 2) \\ STMIK Amik Riau, Teknik Informatika, Jl. merak Gg. Damar Batubelah Kampar \\ email: abdul_aziz@gmail.com \\ STMIK Amik Riau, Teknik Informatika, Jl. Purwodadi Indah Km.10 Panam \\ email:karpen@stmik-amik-riau.ac.id
}

\begin{abstract}
The face is something that is very much considered by both women and men. This is because the face is the first thing seen when meeting someone. However, there are those that often interfere with the face, one of which is a skin disease that is very diverse ranging from acne, dullness, blackheads to cancer. In fact, to overcome this, many people always consult with doctors, especially face problems. One thing that can be done is to diagnose facial skin diseases using the decision tree method and the C4.5 algorithm. The decision tree method is used to find the relationship between the prospective number of variables (data mining), so that it becomes a target variable by classifying it in the form of a decision tree. The results of the classification will be included in the C4.5 algorithm to select variables as roots and branches, where each branch will be given a value. Variables state a parameter that is made as a criterion in decision tree formation. Then the decision tree is to change the form of data into a model rule (guideline) and simplify it in the form of an expert system. This study uses a number of variable symptoms of skin diseases, such as spots and lumps on the skin. This system of diagnosing skin diseases can be used as a guide in performing facial treatments, so that it can avoid skin diseases, especially on the face.
\end{abstract}

Keywords: facial disease, decision tree, $c 4.5$ algorithm

\begin{abstract}
Abstrak
Wajah merupakan hal yang sangat diperhatikan baik oleh perempuan maupun laki-laki. Hal ini disebabkan karena wajah merupakan hal pertama yang dilihat ketika bertemu dengan seseorang. Namun demikian ada yang sering mengganggu pada wajah, salah satunya adalah penyakit kulit yang sangat beragam mulai dari jerawat, kusam, komedo hingga kanker. Pada kenyataannya untuk mengatasi hal ini, maka banyak orang selalu berkonsultasi dengan dokter terutama masalah wajah. Salah satu yang bisa dilakukan adalah dengan melakukan diagnosa penyakit kulit wajah menggunakan metode decession tree dan algoritma C4.5. Metode decision tree digunakan untuk menemukan hubungan antara calon sejumlah variabel (data mining), sehingga menjadi sebuah variabel target dengan mengklasisfikasinya dalam bentuk pohon keputusan. Hasil dari klasifikasi akan dimasukkan dalam algoritma C4.5 untuk dilakukan pemilihan variabel sebagai akar dan cabang, dimana setiap cabang akan diberikan nilai. Variabel menyatakan suatu parameter yang dibuat sebagai kriteria dalam pembentukan pohon keputusan. Selanjutnya pohon keputusan adalah mengubah bentuk data menjadi model rule (pedoman) dan menyederhanakan dalam bentuk sistem pakar. Penelitian ini menggunakan sejumlah variabel gejala penyakit kulit, seperti bintik-bintuk dan benjolan yang ada pada kulit. Adanya sistem diagnosa penyakit kulit ini bisa dijadikan pedoman dalam melakukan perawatan wajah, sehingga bisa terhindar dari penyakit kulit khususnya pada wajah.
\end{abstract}

Kata Kunci: penyakit wajah, pohon keputusan, algoritma C4.5 


\section{PENDAHULUAN}

Wajah merupakan hal sangat diperhatikan baik oleh perempuan maupun laki-laki. Setiap orang menginginkan wajah yang bersih, bagus dan sehat. Karena pertama kali penampilan yang terlihat adalah wajah. Jika wajah sudah terlihat bagus, bersih, segar dan ceria maka keseluruhan penampilan akan terlihat lebih baik. Banyak cara yang digunakan untuk merawat wajah, dengan cara memakai krim, masker atau perawatan wajah lainya. Dari mulai yang murah hingga mahal semua dilakukan untuk perawatan wajah. Adanya penggunaan bahan kimia atau bahan eksternal lainnya mungkin berbahaya bagi wajah. Maka perlu adanya kewaspadaan dalam menggunakan bahan untuk perawatan wajah. Penyakit yang ditimbulkan pada wajah begitu beragam mulai dari yang kecil seperti kulit kering, wajah kusam, jerawat hingga kanker [1] . Masalah yang terjadi dikalangan masyarakat adalah tidak begitu memahaminya bahkan cenderung membiarkan jika terjadi sesuatu dengan wajah. Penelitian ini dilakukan pada beberapa klinik kecantikan yang ada di kota Pekanbaru, melalui wawancara secara langsung dengan dokter spesialis dibidang kecantikan wajah. Hal ini berdasarkan banyaknya pasien yang mminta untuk melakukan perawatan wajah,, khususnya masalah penyakit kulit yang sering terdapat pada wajah.

Faktor yang mempengaruhi mengapa banyak orang membiarkan begitu saja hal-hal yang terjadi pada wajah adalah karena biaya konsultasi untuk dokter yang mungkin tinggi. Situasi tersebut dapat dihindari jika orang tersebut memiliki pengetahuan tentang kesehatan. Pengetahuan dapat diperoleh dari buku-buku atau situs-situs internet yang membahas tentang kesehatan. Akan tetapi untuk mempelajari hal tersebut tidaklah mudah karena selain memerlukan waktu yang cukup lama untuk memahaminya, sumber-sumber tersebut belum tentu dapat mendiagnosis jenis penyakit seperti yang dilakukan oleh seorang dokter [2]. Oleh karena itu diperlukan suatu alat atau sistem yang lebih praktis dan memiliki kemampuan seperti layaknya seorang dokter dalam mendiagnosis penyakit. Caranya adalah melakukan diagnosa awal dengan menggunakan sebuah aplikasi sistem penyakit kulit yang memberikan informasi yang dapat menjadi acuan bagi yang bermasalah dengan kulit wajah agar dapat dilakukan tindakan perawatan selanjutnya. Aplikasi sistem yang dibangun harus menggunakan sebuah metode yang tepat serta melakukan pengambilan data-data dari sejumlah kasus yang ada. Salah satunya adalah dengan metode Decision Tree dan Algoritma C 4.5, yang merupakan sebuah metode dalam data mining yang dapat digunakan untuk mencari data penyebab penyakit kulit wajah.

Penelitian sebelumnya yang menggunakan Algoritma C4.5 sebagai penerapan variabel (data mining) adalah untuk memprediksi nilai kelulusan Siswa Sekolah Menengah berdasarkan aktor eksternal, dimana hasilnya menunjukan bahwa penggunaan Algoritma Decision Tree C4.5 akurat digunakaan dalam prediksi nilai akhir siswa dengan tingkat akurasi 60\% [3]. Penelitian lainnya yang membahas mengenai implementasi klasifikasi Decision Tree dan Algoritma C4.5, yaitu untuk pengambilan keputusan permohonan kredit oleh Debitur, yang menghasilkan kesimpulan bahwa Hasil akhir dari penelitian ini membuktikan bahwa pada kasus ini algoritma C4.5 memiliki tingkat akurasi yang tinggi dan lebih baik dari algoritma ID3 dengan akurasi 96\%. [4]. Melihat hasil akhir dari penelitian yang sudah dilakukan tersebut, maka penggunaan metode Decision Tree dan algoritma C4.5 akan lebih memudahkan untuk proses pencarian variabelnya (data mining).

Berdasarkan uraian yang sudah dijelaskan tersebut di atas, maka yang menjadi rumusan masalah dalam penelitian ini adalah bagaimana membuat sistem diagnosa 
penyakit kulit wajah dengan menggunakan metode decision tree dan algoritma C 4.5, yang memiliki keakuratan data untuk hasil akhirnya dan ini sudah ahas mengenai idibuktikan dengan beberapa penelitian yang sudah dilakukan oleh peneliti sebelumnya. Tujuan dari penelitian ini untuk menghasilkan suatu aplikasi sistem yang dapat digunakan untuk mencari penyebab penyakit kulit wajah dengan menggunakan metode decition tree dan algoritma C4.5. Maka dengan sistem ini diharapkan dapat memecahkan masalah yang ada selama ini, khususnya untuk melakukan perawatan kulit pada wajah yang berhubungan dengan penyakit kulit, sehingga diharapakan dapat membantu semua orang dalam konsultasi mengenai penyakit yang ada pada kulit wajah, membantu pekerjaan dokter kulit karena sistem dapat memberi edukasi kepada pasien mengenai penyakit kulit pada wajah dan membantu meminimalisir penggunaan bahan kimia untuk wajah karena pengetahuan yang diberikan sistem dapat memberi pengetahuan bagi semua orang.

\section{TINJAUAN PUSTAKA}

\subsection{Diagnosis penyakit}

Diagnosis sebagai suatu proses penting pemberian nama dan pengklasifikasian penyakit-penyakit pasien, yang menunjukkan kemungkinan nasib pasien dan yang mengarahkan pada pengobatan tertentu [5]. Proses diagnosa penyakit kulit wajah yang dilakukan adalah dengan menanyakan keluhan-keluhan yang dialami oleh pasien, yang kemudian dibandingkan dengan data-data penyakit kulit yang ada. Diagnosis penyakit kulit wajah dimulai dengan melakukan wawancara kepada pasien yang melakukan perawatan wajah pada klinik medis serta dokter ahli kulit seara medis. Dari diagnosis tersebut akan diperoleh data pertanyaan-pertanyaan yang terarah pada penyakit tertentu. Data yang berhasil dihimpun, akan dipertimbangkan dan diklasifikasikan berdasarkan keluhan-keluhan dari pasien. Dengan demikian penyebab dari gejala-gejala tersebut dapat diketahui dengan mudah dan akhirnya diperoleh kesimpulan awal mengenai penyakit tertentu. Secara etimologi diagnosis berasal dari bahasa Yunani dari kata Gnosis yang artinya adalah Ilmu pengetahuan. Diagnosis merupakan klasifikasi seseorang dengan berdasarkan suatu penyakit yang dideritanya atau satu abnormalitas yang diidapnya.

Istilah diagnosa seringkali kita dengar dalam istilah medis, diagnosa tersebut dapat diartikan sebagai : 1).Upaya atau juga proses dalam menemukan kelemahan atau penyakit (weakness, disease) apa yang dialami seseorang dengan melalui pengujian serta juga studi yang seksama mengenai gejala-gejalanya (symptons); 2).Studi yang seksama terhadap fakta mengenai suatu hal untuk dapat menemukan karakteristik atau juga kesalahan-kesalahan dan sebagainya yang esensial; 3).Keputusan yang dicapai setelah dilakukan suatu studi yang seksama dari segala gejala-gejala atau fakta tentang suatu hal. Diagnosa yang dilakukan memiliki beberapa manfaat, yaitu: 1).Untuk dapat menemukan atau mengidentifikasi kelemahan atau juga penyakit (weakness, disease) apa yang dialami seseorang; 2).Untuk dapat menemukan karakteristik atau juga kesalahan-kesalahan dari gejala-gejala atau faktatentang suatu hal; 3).Sebagai pertimbangan dalam upaya pengendalian penyakit di lapangan; 4).Juga Salah satu dari upaya untuk mencegah serta juga menanggulangi penyebaran suatu penyakit atau wabah.

Kita sering salah dalam membedakan kata diagnostik dengan diagnosa, diagnostik adalah proses perpaduan dari aktifitas intelektual dan manipulatif. Sementara diagnosis 
sendiri didefenisikan sebagai suatu proses penting pemberian nama dan pengklasifikasian penyakit-penyakit pasien, yang menunjukkan kemungkinan nasib pasien dan yang mengarahkan pada pengobatan tertentu [6]. Pada proses ini diagnosa menjadi suatu cara untuk menilai terkena penyakit kulit wajah khususnya berdasarkan dari gejala yang ditimbulkan dan berdasarkan kasus yang sudah pernah terjadi sebelumnya. Dari penjelasan diatas dapat disimpulkan bahwa diagnosis adalah suatu cara menganalisis suatu kelainan dengan mengamati gejala-gejala yang terlihat dan dari gejala tersebut dicari faktor penyebab kelainan tersebut.

\subsection{Penyakit kulit}

Penyakit adalah suatu keadaan abnormal dari tubuh atau pikiran yang menyebabkan ketidaknyamanan, disfungsi atau kesukaran terhadap orang dipengaruhinya, orangorang biasa berkonsultasi dengan seorang dokter. Penyakit kulit wajah merupakan suatu penyakit yang menyerang pada permukaan wajah dan disebabkan oleh berbagai macam penyebab [1]. Penyakit kulit wajah mempunyai macam-macam yang akan menunjukkan varians dalam gejala dan keparahan dan mungkin menampilkan beberapa karakteristik yang unik. Jenis penyakit kulit wajah dapat berkisar dari hampir tidak terlihat hingga mengancam kehidupan. Namun jenis penyakit kulit wajah akan membantu menentukan kemungkinan penyebab dan perawatan terbaik. Beberapa makhluk hidup dapat menyebabkan penyakit kulit wajah dapat diakibatkan oleh makhluk hidup seperti bakteri, virus maupun jamur. Bakteri, virus dan jamur menginfeksi kulit dan dapat merusak kulit wajah. Jenis penyakit kulit antara lain adalah Rosacea, dengan gejalanya kulit kemerahan, muncul bintik-bintik berlebihan, pembengkakan, Skin Tag, gejalanya muncul benjolan kecil berupa kelejanr minyak yang membesar, warna merah kekuningkuningan, Milia, gejalanya bintik-bintik kecil berwarna putih, tumbuh di kelopak mata dan pipi, Jerawat, gejalanya benjolan yang berwarna merah, dan jika sudah matang akan berisi cairan yang berwarna kuning.

\subsection{Decision Tree (Pohon Keputusan)}

Pohon keputusan berguna untuk mengekspolari data, menemukan hubungan tersembunyi antara sejumlah calon variabel dengan sebuah variabel target. Pohon keputusan merupakan metode klasifikasi dan prediksi yang sangat kuat dan terkenal. Metode pohon keputusan mengubah fakta yang sangat besar menjadi pohon keputusan yang merepresentasikan aturan. Data dalam pohon keputusan biasanya dinyatakan dalam bentuk table dengan atribut dan record. Atribut menyatakan suatu parameter yang dibuat sebagai criteria dalam pembentukan pohon. Atribut memiliki nilai-nilai dinamakan instanc [7]. Proses pada pohon keputusan adalah mengubah bentuk data (table) menjadi model pohon, mengubah model pohon menjdi rule, dan menyederhanakan rule. Banyak algoritma yang dapat digunakan dalam pembentukan pohon keputusan, antara lain ID3, CART, dan C4.5

\subsubsection{Algoritma C4.5}

Algoritma C4.5 merupakan pengembangan dari algoritma ID3. Oleh karenanya memiliki prinsip dasar kerja yang sama dengan algoritma ID3 [8]. Secara umum algoritma $\mathrm{C} 4.5$ dapat dibangun menggunakan pohon keputusan dengan cara:

a. Pilih atribut sebagai akar

b. Buat cabang untuk tiap-tiap nilai

c. Bagi kasus dalam cabang

d. Ulangi proses untuk setiap cabang sampai semua kasus pada cabang memilki kelas yang sama.

Penggunaan algoritma C4.5 dengan pohon keputusan adalah sebagai berikut: 


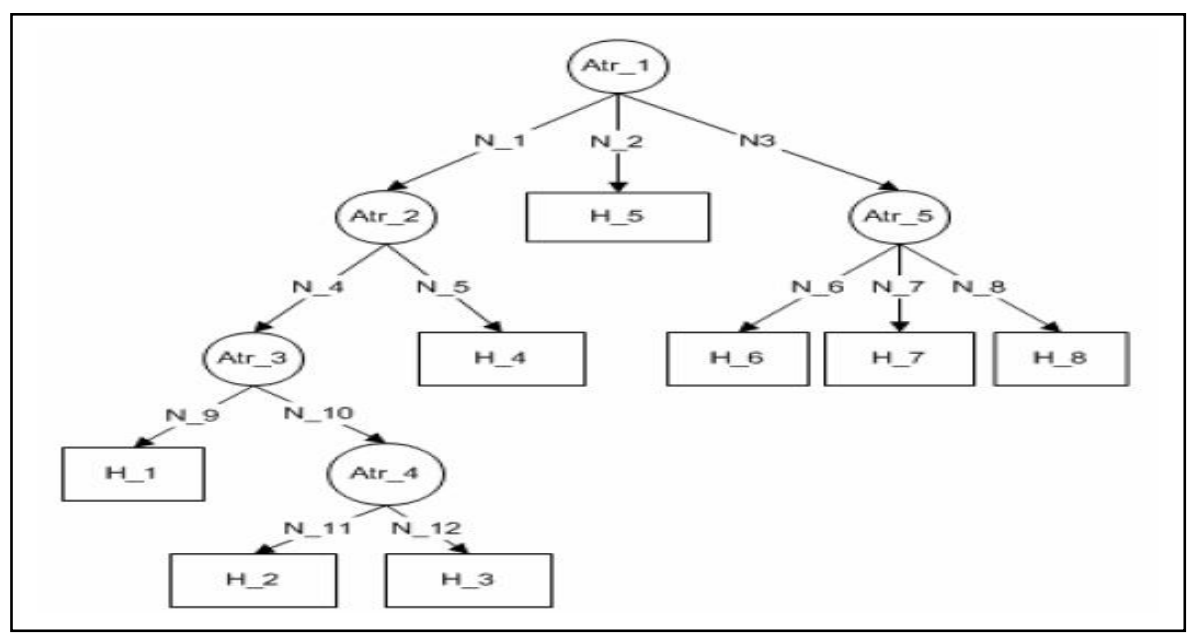

Gambar 2.1 Penggunaan algoritma C4.5 dengan metode decision tree

Untuk memilih atribut sebagai akar, didasarkan pada nilai gain tertinggi dari atributatribut yang ada. Adapun rumus tersebut adalah:

$$
\operatorname{Gain}(S, A)=\operatorname{Entropy}(S)-\sum_{i=1}^{n} \frac{\|s i\|}{\|s\|} * \operatorname{Entropy}(S i)
$$

Keterangan :

$$
\begin{array}{ll}
\mathrm{S} & =\text { Himpunan Kasus } \\
\mathrm{A} & =\text { Atribut } \\
\mathrm{n} & =\text { Jumlah partisi atribut A } \\
|s i| & =\text { Jumlah kasus pada partisi ke-i } \\
|s| & =\text { Jumlah kasus dalam } \mathrm{s}
\end{array}
$$

Entropy bisa dikatakan sebagai kebutuhan bit untuk menyatakan suatu kelas. Semakin kecil nilai entropy maka semakin baik untuk digunakan mengekstraksi suatu kelas. Untuk menghitung nilai entropy, adapun rumus tersebut:

$$
\operatorname{Entropy}(S)-\sum_{i=1}^{n}-p i * \log 2 p i
$$

Keterangan :

$$
\begin{array}{ll}
\mathrm{S} & =\text { himpunan kasus } \\
\mathrm{A} & =\text { fitur } \\
\mathrm{n} & =\text { jumlah partisi } \mathrm{S} \\
\mathrm{pi} & =\text { proporsi dari } \mathrm{S}_{\mathrm{i}} \text { terhadap } \mathrm{S}
\end{array}
$$

\subsubsection{Sistem Pakar}

Pada analisa yang didapat di lapangan, proses yang terjadi dalam penentuan hasil pakar dalam menangani kasus penyakit kulit wajah adalah dengan cara melihat gejalagejala yang di timbulkan pada wajah, kemudian dapat mendiagnosa jenis penyakit yang diderita oleh pasien. Proses awal yang terjadi adalah seorang dokter spesialis kecantikan dan kulit wajah akan memeriksa kondisi pasien dilihat dari gejala-gejala yang ditimbulkan atau dirasakan (sebagai sistem pakar). Selanjutnya dokter memeriksa dan melakukan diagnosa terhadap gejala yang ditimbulkan. Pasien yang mengalami gejalagejala yang ditimbulkan akan diberikan pengobatan agar kulit wajah menjadi sehat. Ada dua aktor yang berperan nantinya dalam sistem yang dibangun yaitu pakar dan perawat. Pakar melakukan input berupa penyakit, gejala dan kasus. Sedangkan perawat 
melakukan penginputan data-data pasien. Penggunaan sistem pakar dalam aplikasi sistem ini dapat dilihat pada gambar 2.2 berikut:

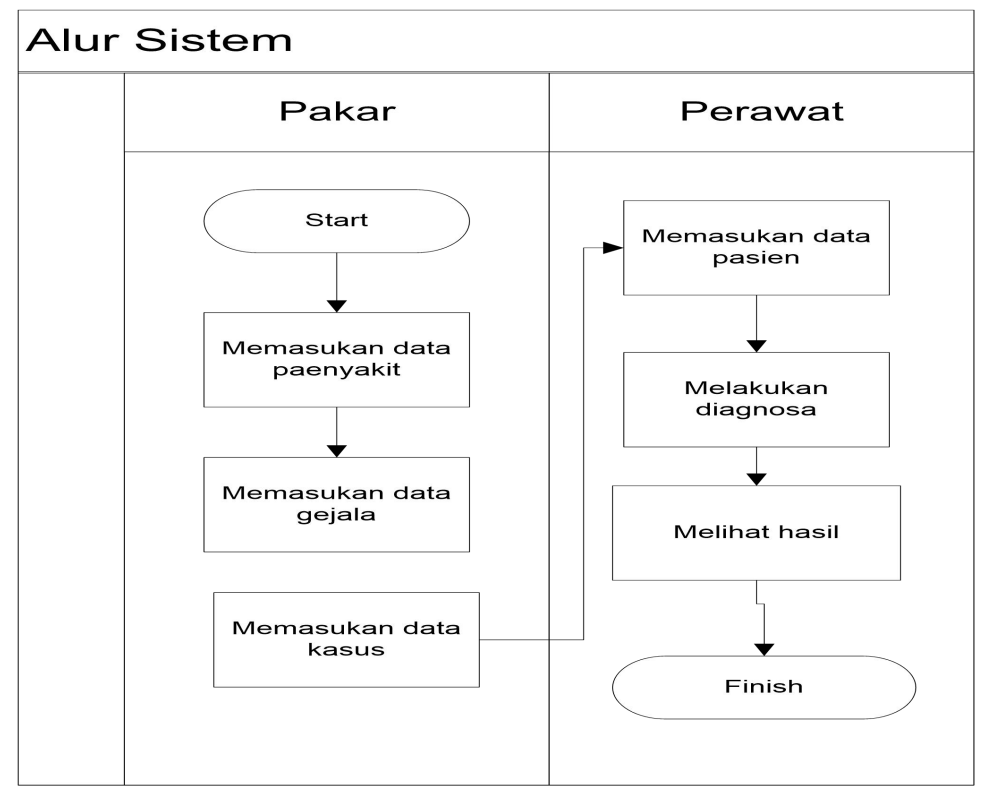

Gambar 2.2 Penggunaan sistem pakar dalam aplikasi sistem

Sistem pakar (expert system) merupakan perangkat lunak berbasis pengetahuan yang meniru kepakaran para ahli dalam sebuah bidang. Sistem pakar dirancang untuk memecahkan suatu permasalahan dengan meniru kerja dari para ahli. Kepakaran (expertise) adalah pengetahuan yang ekstensif dan spesifik yang diperoleh melalui rangkaian pelatihan, membaca, dan pengalaman [9]. Pengetahuan membuat pakar dapat mengambil keputusan secara lebih baik dan lebih cepat daripada non-pakar dalam memecahkan problem yang kompleks. Kepakaran mempunyai sifat berjenjang, pakar top memiliki pengetahuan lebih banyak daripada pakar yunior. Tujuan Sistem Pakar adalah untuk mentransfer kepakaran dari seorang pakar ke komputer, kemudian ke orang lain (yang bukan pakar).

Secara garis besar, banyak manfaat yang dapat diambil dengan adanya sistem pakar, antara lain [10]: 1).Memungkinkan orang awam bisa mengerjakan pekerjaan para ahli; 2).Bisa melakukan proses secara berulang secara otomatis; 3).Menyimpan pengetahuan dan keahlian para pakar; 4).Meningkatkan output dan produktivitas; 5).Meningkatkan kualitas dan 6).Mampu mengambil; 7).Melestarikan keahlian para pakar (terutama yang termasuk keahlian langka); 8).Meningkatkan kapabilitas dalam penyelesaian masalah dan 9).Menghemat waktu dalam pengambilan keputusan.

\section{METODE PENELITIAN}

Dalam penelitian ini, metode yang digunakan adalah Waterfall karena metode ini cocok sebagai bentuk untuk memberikan solusi yang tepat, sesuai dengan tahapannya. Selanjutnya untuk melakukan perancangan sistemnya menggunkaan Unified Modelling Language (UML) seperti use case, activity diagram, sequent diagram dan class diagram dan menggunkaan bahasa pemrograman yang berorientasi visual yaitu dengan PHP dan database My SQL.

\subsection{Analisa Data}

Analisa yang dilakukan adalah dengan mendapatkan sejumlah data-data di lapangan (klinik kecantikan wajah), yang selanjutnya ditentukan dengan penentuan hasil pakar 
dalam menangani kasus penyakit kulit wajah adalah dengan cara melihat gejala-gejala yang di timbulkan pada wajah, kemudian dapat mendiagnosa jenis penyakit yang di derita oleh pasien. Proses awal yang terjadi adalah seorang dokter spesialis kecantikan dan kulit wajah akan memeriksa kondisi pasien dilihat dari gejala-gejala yang ditimbulkan atau dirasakan. Kemudian dokter memeriksa dan melakukan diagnosa terhadap gejala yang ditimbulkan. Pasien yang mengalami gejala-gejala yang ditimbulkan akan diberikan pengobatan. Dari analisa yang dilakukan maka didapatkan:

Tabel 3.1 Tabel gejala penyakit kulit wajah

\begin{tabular}{|c|l|l|}
\hline Kode Gejala & Nama Gejala & Kategori \\
\hline G01 & Bintik bintik & Gejala \\
\hline G02 & Benjolan & Gejala \\
\hline G04 & Sakit disentuh & Efek \\
\hline G05 & Muka berminyak & Efek \\
\hline G10 & 10 sd 18 & Usia \\
\hline G13 & $>40$ & Usia \\
\hline
\end{tabular}

Tabel 3.2 Tabel penyakit wajah

\begin{tabular}{|l|l|l|l|}
\hline $\begin{array}{l}\text { Kode } \\
\text { Penyakit }\end{array}$ & $\begin{array}{l}\text { Nama } \\
\text { Penyakit }\end{array}$ & Defenisi & Solusi \\
\hline P01 & Rosacea & $\begin{array}{l}\text { Penyakit ruam kronis dimana } \\
\text { gejalanya kilit diwajah menjadi } \\
\text { kemerahan dengan muncul bintik- } \\
\text { bintik berlebihan serta } \\
\text { pembengkakan }\end{array}$ & Facial,Operasi \\
\hline P02 & Milia & $\begin{array}{l}\text { Bintik-bintik kecil berwarna putih } \\
\text { yang tumbuh di sekitar kelopak } \\
\text { mata dan pipi. }\end{array}$ & Operasi Laser \\
\hline P03 & Skintags & $\begin{array}{l}\text { Bentuknya hampir sama dengan } \\
\text { tahi lalat, yakni benjolan kecil di } \\
\text { beberapa tempat, yang } \\
\text { membedakan dengan tahi lalat } \\
\text { adalah warnanya yang tidak selalu } \\
\text { hitam melainkan terkadang } \\
\text { bening. Biasanya banyak muncul } \\
\text { di bawah mata pipi, ketiak, } \\
\text { pangkal paha dan bawah } \\
\text { payudara. }\end{array}$ & \\
\hline P04 & $\begin{array}{l}\text { masalah kulit yang ditandai } \\
\text { dengan munculnya bintik-bintik } \\
\text { pada beberapa bagian tubuh, } \\
\text { seperti wajah, leher, punggung, } \\
\text { dan dada. Facial,Obat Jerawat }\end{array}$ & \\
\hline
\end{tabular}

Sumber: dr.Khairani Shaleh, 2017 
Hal : $74-86$

Tabel 3.3 Tabel kasus penyakit kulit wajah

\begin{tabular}{|l|l|l|l|l|l|}
\hline No & Gejala & Efek & tampilan & usia penderita & Penyakit \\
\hline 1 & Benjolan & sakit disentuh & merah & 16 & Jerawat \\
\hline 2 & bintik-bintik & $\begin{array}{l}\text { muka berminyak, } \\
\text { kusam }\end{array}$ & putih & 18 & Jerawat \\
\hline 3 & Buka berminyak, & hitam & 43 & Skin Tag \\
\hline 4 & $\begin{array}{l}\text { Kemerahan di } \\
\text { kulit wajah }\end{array}$ & sakit disentuh & merah & 29 & Rosacea \\
\hline 5 & bintik-bintik & sakit disentuh & hitam & 16 & Skin Tag \\
\hline 6 & bintik-bintik & sakit disentuh & merah & 10 & Jerawat \\
\hline
\end{tabular}

\subsection{Diagnosa Penyakit Kulit Wajah}

Dari rumus yang sudah ditentukan sebelumnya pada algorita $\mathrm{C} 4.5$, dalam diagnosis ini usia penderita sengaja diambil berdasarkan data-data yang ada, yaitu usia yang bervariasi antara umur 10 tahun sampai dengan usia 43 tahun, maka dapat dilakukan perhitungan dan dihasilkan tabel decision tree sebagai berikut:

Proses perhitungan nilai gain dan entrophy:

Entrophy $[$ Total] $=(-(8 / 15) *(\log 2(8 / 15))+(-(2 / 15) *(\log 2(2 / 15))+(-(3 / 15) *(\log 2$ $(3 / 15))+(-(2 / 15) *(\log 2(2 / 15))=1.723231$

Entrophy [gejala - bintik bintik] $=(-(2 / 5) *(\log 2(2 / 5))+(-(2 / 5) *(\log 2(2 / 5))+(-(1 / 5)$ $*(\log 2(1 / 5))+(-(0 / 5) *(\log 2(0 / 5))=$ Tak Terhingga, Apabila hasil tidak ditemukan maka diganti dengan 0

Entrophy [gejala - benjolan] $=(-(5 / 7) *(\log 2(5 / 7))+(-(0 / 7) *(\log 2(0 / 7))+(-(2 / 7) *$ $(\log 2(2 / 7))+(-(0 / 7) *(\log 2(0 / 7))=$ Tak Terhingga, Apabila hasil tidak ditemukan maka diganti dengan 0

Entrophy [gejala - kemerahan diwajah] $=(-(1 / 3) *(\log 2(1 / 3))+(-(0 / 3) *(\log 2(0 / 3))$ $+(-(0 / 3) *(\log 2(0 / 3))+(-(2 / 3) *(\log 2(2 / 3))=$ Tak Terhingga, Apabila hasil tidak ditemukan maka diganti dengan 0

Gain $[$ Pelatih $]=1.723231-((5 / 15) * 0)+((7 / 15) * 0)+((3 / 15) * 0)=1,723231$

dan seterusnya...,

Dari perhitungan tersebut dapat dihasilkan tabel decision tree sebagai berikut:

Tabel 3.4 Tabel Decision Tree dari perhitungan algoritma C4.5

\begin{tabular}{|c|c|c|c|c|c|c|c|c|}
\hline & & $\begin{array}{l}\text { juml } \\
\text { ah } \\
\text { kasu } \\
\text { s }\end{array}$ & $\begin{array}{l}\text { Jera } \\
\text { wat }\end{array}$ & $\begin{array}{l}\text { Mil } \\
\text { ia }\end{array}$ & $\begin{array}{l}\text { Skin } \\
\text { Tag }\end{array}$ & Rosacea & entropy & gain \\
\hline Total & & 15 & 8 & 2 & 3 & 2 & $\begin{array}{r}1,7232 \\
31 \\
\end{array}$ & \\
\hline Gejala & & & & & & & & $\begin{array}{r}1,72 \\
3231 \\
\end{array}$ \\
\hline & bintik-bintik & 5 & 2 & 2 & 1 & 0 & 0 & \\
\hline & Benjolan & 7 & 5 & 0 & 2 & 0 & 0 & \\
\hline Efek & & & & & & & & $\begin{array}{r}1,18 \\
9 \\
\end{array}$ \\
\hline & sakit disentuh & 6 & 4 & 0 & 1 & 1 & 0 & \\
\hline Tampilan & & & & & & & & 1,72 \\
\hline
\end{tabular}


Hal : $74-86$

\begin{tabular}{|l|l|r|r|r|r|r|r|r|}
\hline & & & & & & & & 32 \\
\hline & Warna hitam & 4 & 1 & 0 & 2 & 1 & 0 & \\
\hline & warna putih & 3 & 1 & 1 & 1 & 0 & 0 & \\
\hline & Warna merah & 8 & 6 & 1 & 0 & 1 & 0 & \\
\hline $\begin{array}{l}\text { usia } \\
\text { penderita }\end{array}$ & & & & & & & & 1,72 \\
\hline & $10 \mathrm{sd} 18$ & 3 & 2 & 0 & 1 & 0 & 0 & 32 \\
\hline & $>40$ & 2 & 0 & 0 & 2 & 0 & 0 & \\
\hline
\end{tabular}

Dari hasil tabel tersebut, selanjutnya dapat dilakukan analisis untuk kemudian dimasukkan ke dalam algoritma Decision tree C4.5 yang dapat digambarkan sebagai berikut:

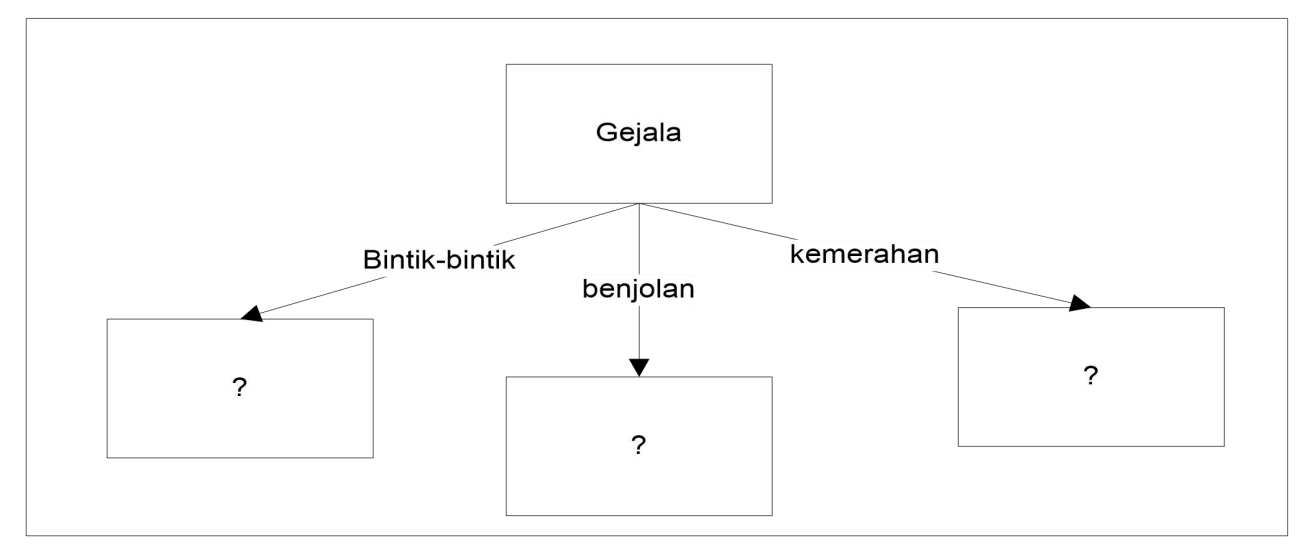

Gambar 3.2.1 Decision Tree dari data hasil perhitungan algoritma C4.5

Dari gambar yang di atas belum ditemukan gejala-gejala penyakulit wajah yang ditemukan, untuk itu harus dilakukan perhitungan selanjutnya. Pencarian berikutnya dilakukan pada hasil tree yang masih kosong atau memiliki kemungkinan penyakit yang lebih dari satu maka dilakukan pencarian pada Efek Muka berminyak.

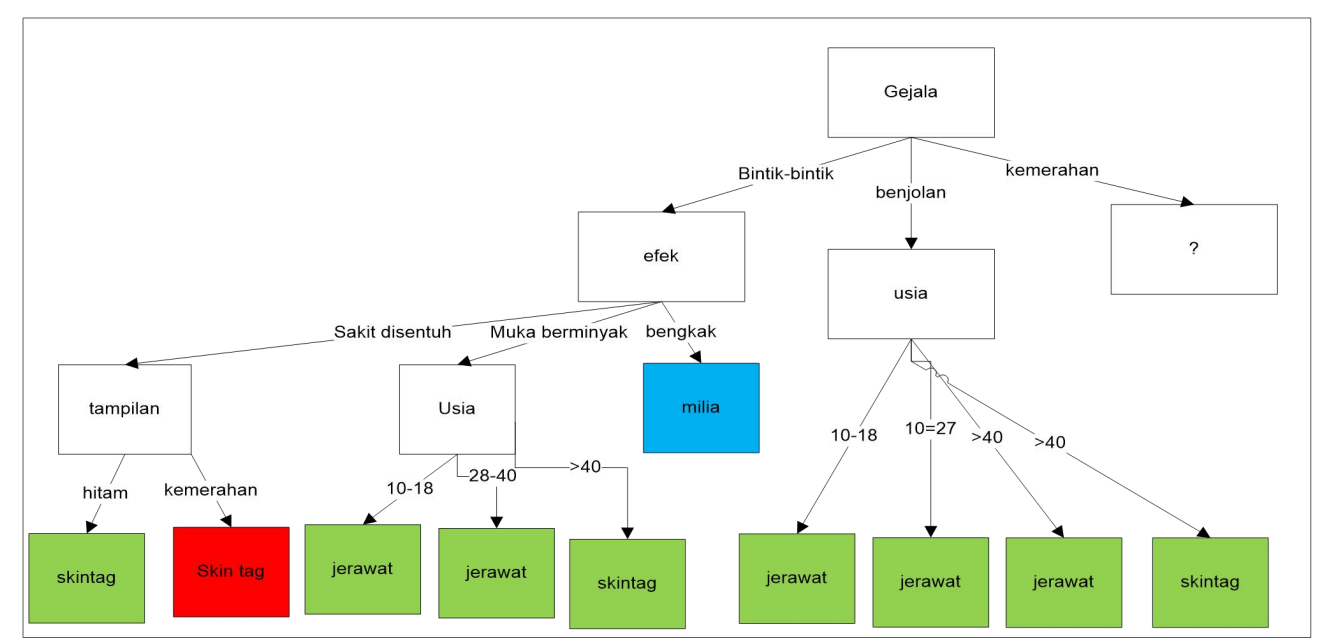

Gambar 3.2.2 Hasil Algoritma 4.5 dengan Decision Tree

Dari data gejala sudah semua ditemukan dan pohon keputusan yang akan dijadikan basis pengetahuan pada sistem pakar sudah ditemukan maka pencarian selesai. Berdasarkan hasil akhir dari pohon keputusan dapat di berikan contoh mengenai proses diagnosa sistem pakar. Berikut contohnya :Apabila di ketahui gejala yang di timbulkan adalah :G01 (bintik-bintik), G05 (muka berminyak), G10 (usia 10-18). Maka 
Hal : $74-86$

berdasarkan pencarian pada pohon keputusan (Decision Tree) di atas hasilnya adalah pasien terkena penyakit Jerawat. Hasil akhir diagnosa dengan algoritma Decusion tree adalah sebagai berikut:

Tabel 3.5. Tabel Hasil Diagnosa

\begin{tabular}{|l|l|l|l|l|}
\hline Gejala & Bintik bintik & Muka berminyak & Usia 10-18 & Jerawat \\
\hline Gejala & Bintik bintik & Sakit disentuh & $\begin{array}{l}\text { Warna } \\
\text { hitam }\end{array}$ & Skintag \\
\hline Gejala & Bintik bintik & Muka berminyak & Usia $>40$ & Skintag \\
\hline Gejala & Benjolan & Usia Penderita $>40$ & & Skintag \\
\hline Gejala &
\end{tabular}

\subsection{Perancangan Sistem}

Perancangan sistem yang diusulkan adalah pendekatan yang berorientasi objek, dimana perancangannya menggunakan $U M L$ seperti, Uses case diagram, Sequence diagaram, Activity diagram dan Class diagram serta database My SQL.

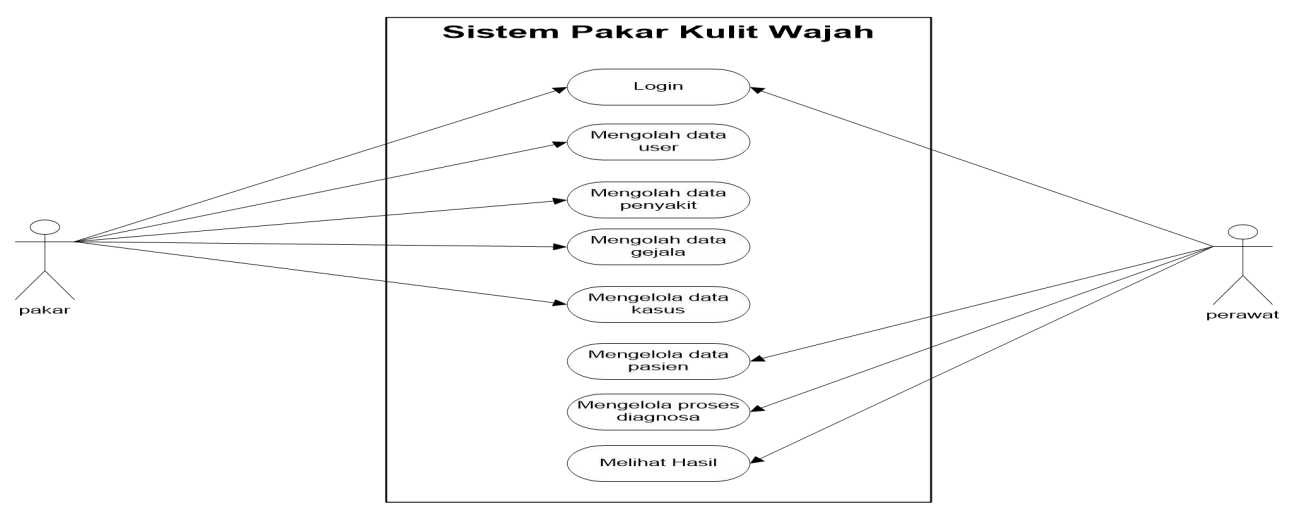

Gambar 3.3.1 Perancangan Use Case Diagram

Use Case Diagram tersebut menjelaskan bahwa, user memiliki wewenang masingmasing untuk dapat menjalankan fungsi asing-asingnya yang ada di dalam sistem. Untuk itu setiap user harus melakukan login terlebih dahulu.

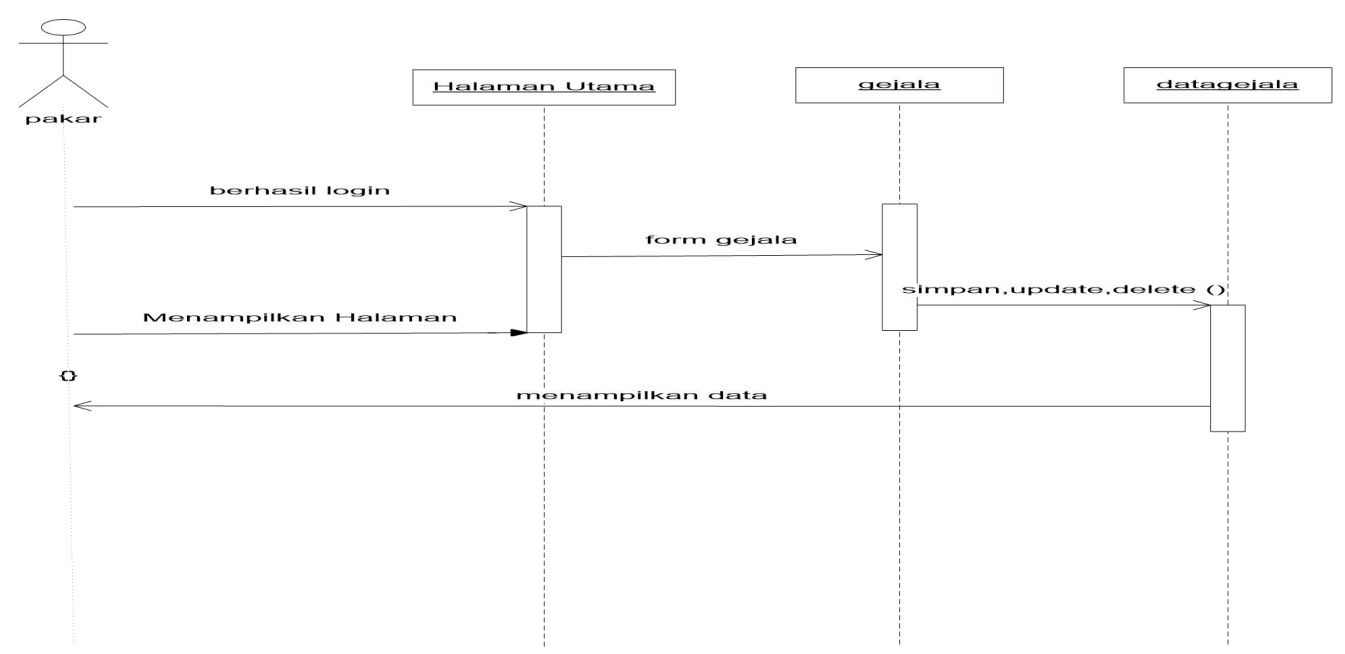

Gambar 3.3.2 Sequence Diagram gejala penyakit kulit 


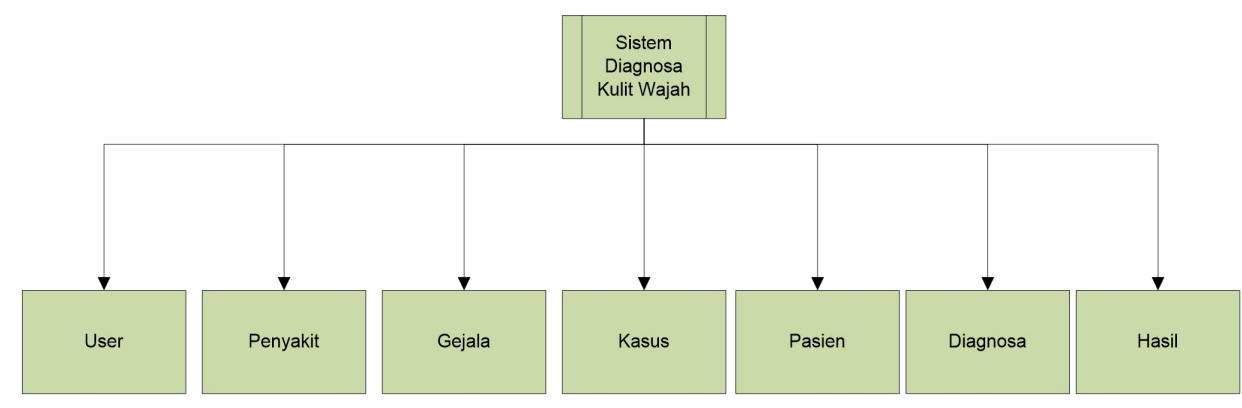

Gambar 3.3.3 Struktur tampilan aplikasi sistem

\section{HASIL DAN PEMBAHASAN}

Setiap user (pengguna sistem) harus login terlebih dahulu, baru kemudian bisa melanjutkan dengan aktifitas lain yang dapat dilihat pada halaman menu utama sebagai berikut:

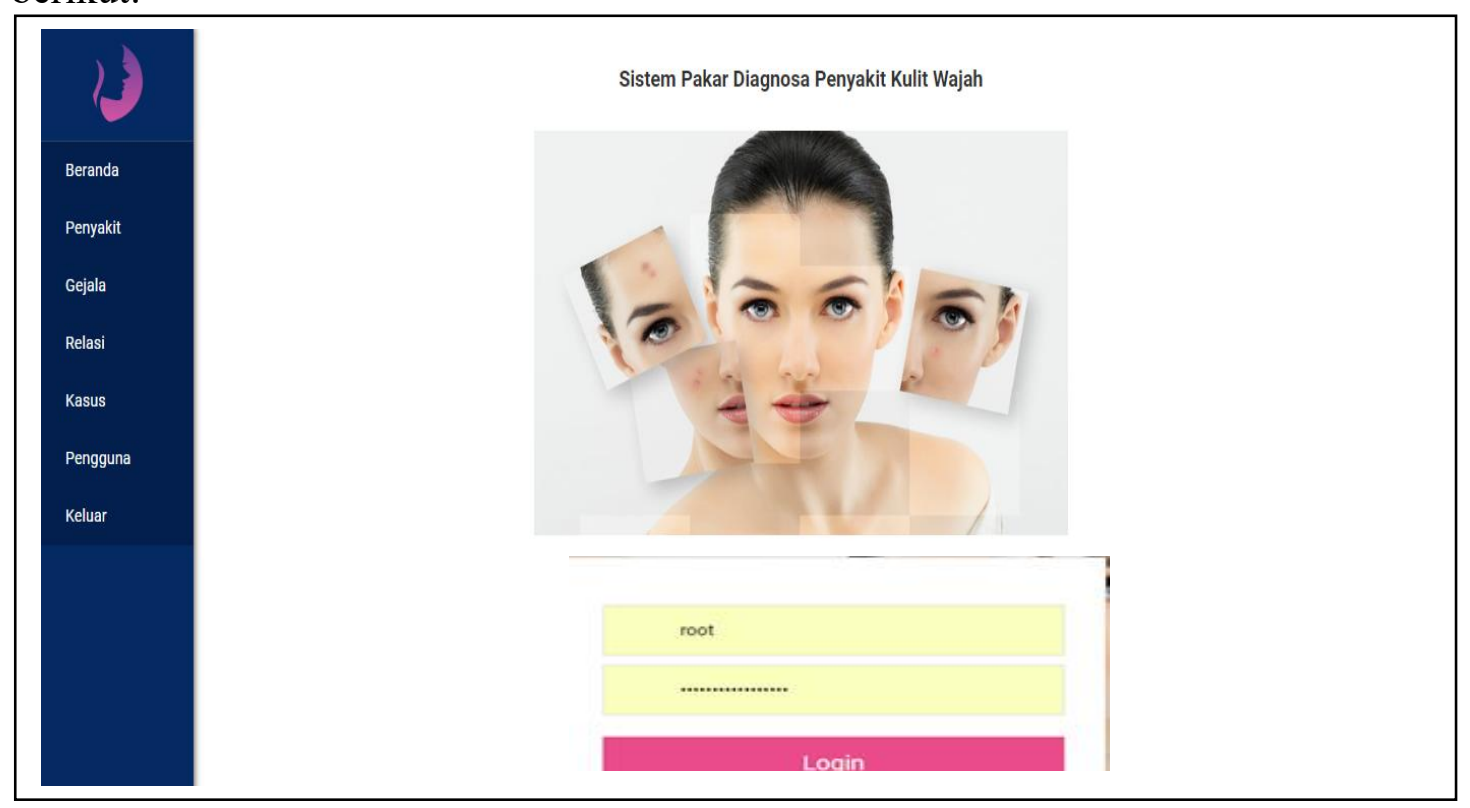

Gambar 4.1 Menu utama diagnosa penyakit kulit wajah

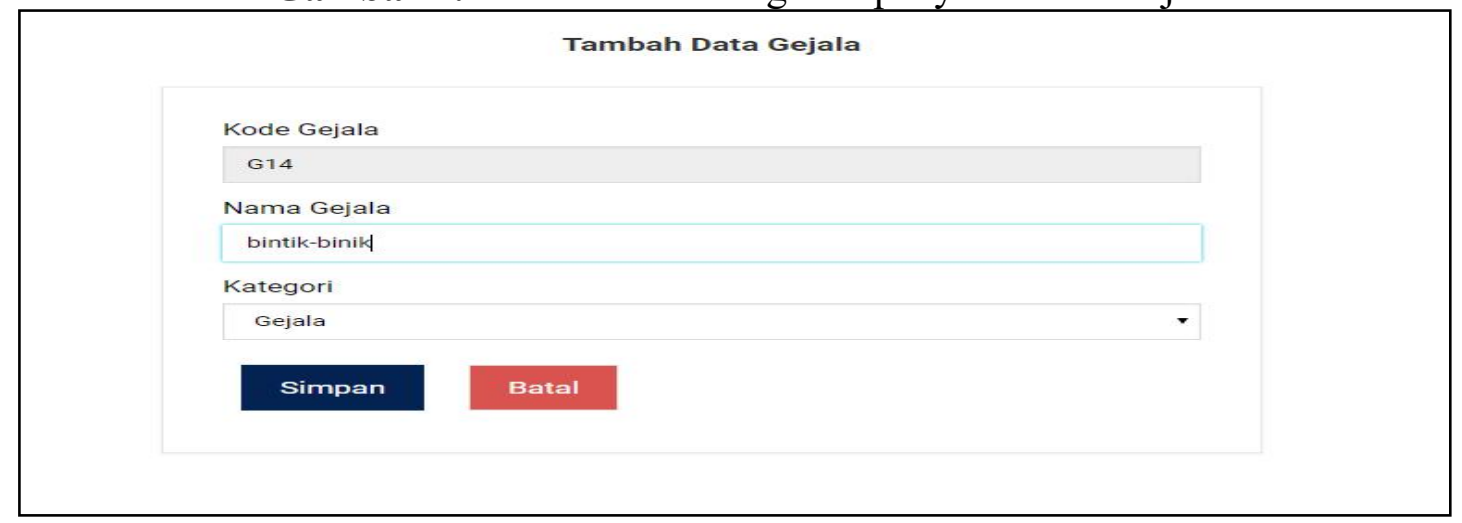

Gambar 4.2 Tampilan untuk menambahkan data

Dari tampilan tersebut user bisa melakukan kegiatan penambahan data-data penyakit beserta dengan diagnosa gejala-gejala yang ditimbulkannya, dan selanjutnya disimpan. 

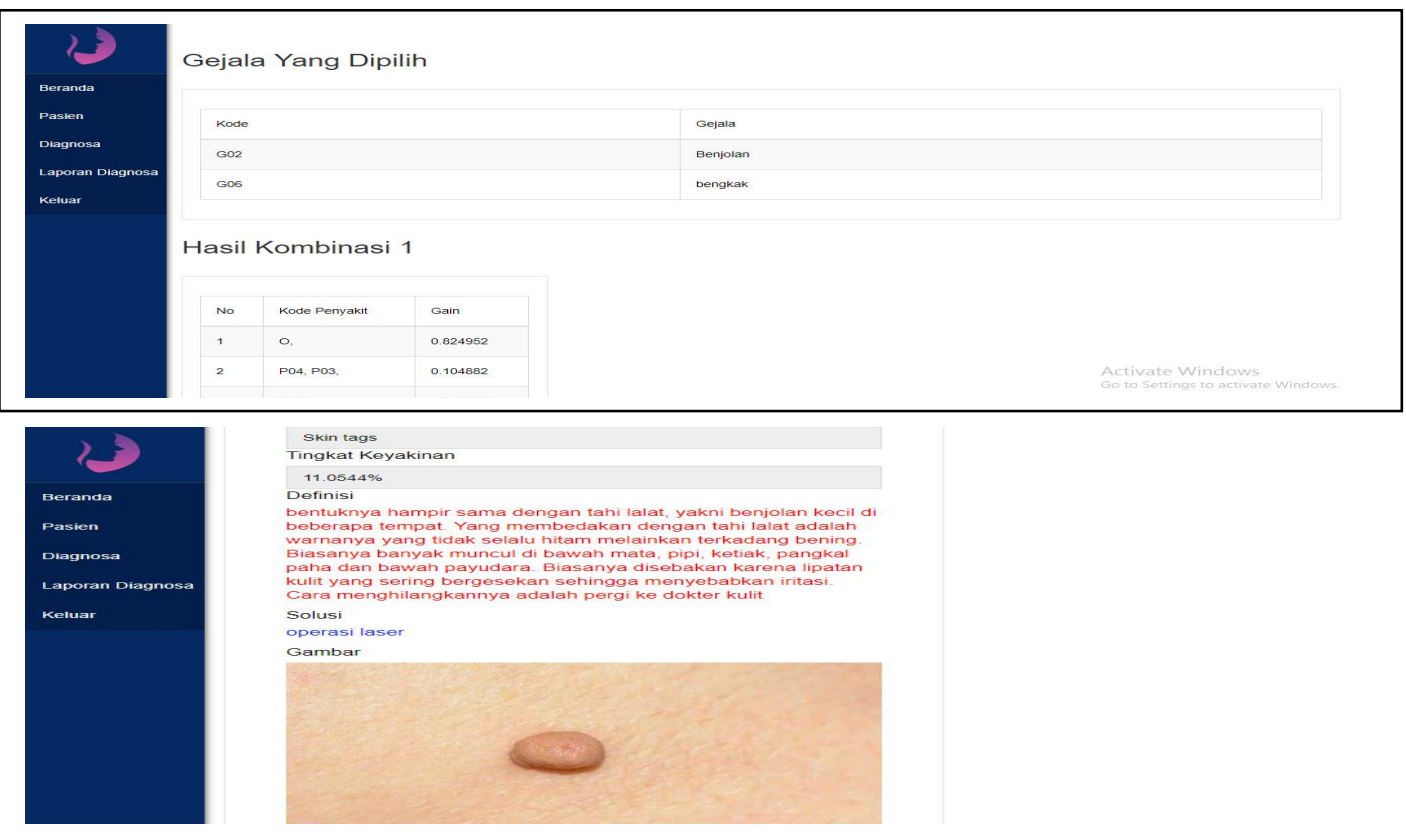

Gambar 4.3 Tampilan hasil diagnosa penyakit kulit

Selanjutnya adalah dengan melakukan pengujian sistem, dalam hal ini teknik pengujiannya menggunakan Black Box, yaitu pengujian terhadap sistem yang sudah selesai berjalan dengan baik atau tidak. Hasilnya dapat dilihat pada tabel berikut:

Tabel 4.1 Pengujian dengan Black Box

\begin{tabular}{|l|l|l|l|l|}
\hline Form Uji & Data masukan & $\begin{array}{c}\text { Harapan } \\
\text { pengujian }\end{array}$ & Hasil pengujian & \multicolumn{1}{|c|}{ Kesimpulan } \\
\hline user & $\begin{array}{l}\text { Mengisi field } \\
\text { data user }\end{array}$ & $\begin{array}{l}\text { Field data } \\
\text { user dapat } \\
\text { tersimpan }\end{array}$ & $\begin{array}{l}\text { Data user dapat } \\
\text { tersimpan pada } \\
\text { database }\end{array}$ & $\begin{array}{l}{[\sqrt{ }] \text { Berhasil }} \\
{[\text { ] Tidak Berhasil }}\end{array}$ \\
\hline gejala & $\begin{array}{l}\text { Mengisi field } \\
\text { data gejala } \\
\text { dengan cara } \\
\text { klik tombol } \\
\text { "gejala". }\end{array}$ & $\begin{array}{l}\text { Field } \text { data } \\
\text { gejaladapat } \\
\text { tersimpan }\end{array}$ & $\begin{array}{l}\text { Data gejaladapat } \\
\text { tersimpan pada } \\
\text { database setelah } \\
\text { klik }\end{array}$ & $\begin{array}{l}{[\sqrt{ } \text { ] Berhasil }} \\
{[\text { ] Tidak Berhasil }}\end{array}$ \\
\hline diagnosa & $\begin{array}{l}\text { Memilih } \\
\text { diagnosanya }\end{array}$ & $\begin{array}{l}\text { Field } \text { data } \\
\text { diagnosa }\end{array}$ & $\begin{array}{l}\text { Data diagnosa } \\
\text { dapat diubah. }\end{array}$ & $\begin{array}{l}\text { [ V ] Berhasil } \\
\text { [ ] Tidak Berhasil }\end{array}$ \\
\hline
\end{tabular}

\section{KESIMPULAN}

Setelah menyelesaikan serangkaian tahapan terhadap pembuatan sistem diagnosa penyakit kulit wajah, sistem berjalan baik dan dapat menghasilkan ketepatan data, seperti jika diketahui gejala yang di timbulkan adalah :G01 (bintik-bintik), G05 (muka berminyak), G10 (usia 10-18). Maka berdasarkan pencarian pada pohon keputusan (Decision Tree) hasilnya adalah pasien terkena penyakit Jerawat. Penggunaan metode Decision Tree dan penerapan Algoritma C4.5 memberikan hasil sesuai dengan data yang dimasukan. 


\section{UCAPAN TERIMA KASIH}

Terima kasih kami ucapkan kepada pihak ejournal UNIKS yang sudah bersedia untuk menerbitkan makalah ini pada Jurnal teknologi dan Open Source (JTOS), STMIK Amik Riau home base penulis sebagai Dosen, Reviewer yang sudah memberikan masukan dan arahannya serta semua pihak yang telah membantu dalam penelitian dan penulisan makalah ini yang tidak bisa disebutkan satu persatu.

\section{DAFTAR PUSTAKA}

[1] F. Riandari, "SISTEM PAKAR MENDIAGNOSA PENYAKIT KULIT WAJAH," vol. 1, no. 2, pp. 85-89, 2017.

[2] R. H. Usep tatang Suryadi, "Implementasi metode Naive Bayes untuk menganalisis penyakit pasien," Teknol. Inf. dan Komun. STmIK Subang, vol. 6, no. 2, pp. 1-16, 2015.

[3] R. H. Pambudi and B. D. Setiawan, "Penerapan Algoritma C4 . 5 Untuk Memprediksi Nilai Kelulusan Siswa Sekolah Menengah Berdas arkan Faktor Eksternal," vol. 2, no. 7, pp. 2637-2643, 2018.

[4] R. K. Amin, D. Indwiarti, M. Si, Y. Sibaroni, and S. Si, "IMPLEMENTASI KLASIFIKASI DECISION TREE DENGAN ALGORITMA C4 . 5 DALAM PENGAMBILAN KEPUTUSAN PERMOHONAN KREDIT OLEH DEBITUR Prodi lmu Komputasi Fakultas Informatika," vol. 2, no. 1, 2015.

[5] D. J. D. Annisa Nurul fadhillah, Dini Destini, "Perancangan alikasi sistem pakar penyakit kulit pada anak dengan metode ekpert system development life cycle," Algoritm. STT Garut, vol. 3, no. 1, pp. 1-7, 2015.

[6] M. Turnip, "Sistem Pakar Diagnosa Penyakit THT Menggunakan Metode Backward Chaining," no. January 2015, 2017.

[7] E. L. Taufik, "Penerapan Data mining Algortima asosiasi untuk meningatkan produk penjualan," J. DASI, vol. 10, no. 1, pp. 1-21, 2013.

[8] W. D. Septiani, "Penerapan Algoritma C4.5 untuk prediksi penyakit Hepatitis," Tekno Nusa mandiri, vol. XI, no. 1, pp. 69-78, 2014.

[9] P. Bidang et al., "Jurnal Edik Informatika SISTEM PAKAR DIAGNOSA PENYAKIT ALERGI PADA ANAK BERBASIS WEB DENGAN METODE FORWARD CHAINING Jurnal Edik Informatika," vol. 2, pp. 197-205, 2017.

[10] I. S. Hafsah, P. N. Andono, and J. N. N. Semarang-, "Deteksi Otomatis Penyakit Kulit Menggunakan Algoritma Naive Bayes,” no. 5, pp. 1-6. 